\title{
DEKONSTRUKSI MAKNA PELACUR DALAM ATAS NAMA MALAM KARYA SENO GUMIRA AJIDARMA
}

\section{MEANING DECONSTRUCTION OF PROSTITUTE IN ATAS NAMA MALAM OF SENO GUMIRA AJIDARMA}

\author{
Ricky Aptifive Manik \\ Kantor Bahasa Provinsi Jambi
}

\begin{abstract}
Prostitutes often get a negative meaning, not only in their profession but also in their identity markers. This stigma has put them in a low hierarchy compared to other professions as their opposite meaning. This research aims to find out various binary oppositions related to prostitute, dominant logic, and meaning invention of prostitute in a collection of short stories of Atas Nama Malam of Seno Gumira Ajidarma. The problem in this study is what is binary opposition, the dominant logic in the text and how the invention of the meaning of the prostitute after being deconstructed in SGA's short stories. This study used Derrida's deconstruction method with a comprehensive reading strategy in searching for binary oppositions of prostitute. Reconstruction of the text was also carried out to find the dominant logic contained in the text, including the interpretation of other assumptions to then be distorted from the hierarchical structure of the binary oppositions, that is finding the invention of meaning. This study found that there were seven binary oppositions of prostitute, namely a man, morning/afternoon worker, doctor, teacher, official wife, murderer, and harmonious family shaper. The meaning of prostitute finds its invention as the people who are responsible for her family, helper/hero, honest, and victim.
\end{abstract}

Key words: prostitute, deconstruction, meaning, short stories

\begin{abstract}
ABSTRAK
Pelacur acapkali mendapatkan pemaknaan negatif, baik dalam profesi maupun penanda identitasnya. Stigma ini memosisikan pelacur pada hierarki yang rendah dibandingkan profesi lain sebagai oposisi pemaknaannya. Tujuan penelitian ini untuk mengetahui berbagai oposisi biner terkait pelacur, logika dominan, dan invensi makna pelacur yang terdapat di dalam kumpulan cerpen karya Seno Gumira Ajidarma. Masalah dalam penelitian ini adalah mengapa pelacur ditempatkan pada posisinya yang rendah daripada oposisinya dan bagaimana teks cerpen justru menghancurkan hierarki tersebut dan menemukan maknanya yang baru. Penelitian ini menggunakan metode dekonstruksi Derrida dengan tiga strategi pembacaan cermat, pertama, mengklasifikasi oposisi biner yang ada dalam tiap-tiap cerpen; kedua, melakukan rekonstruksi teks untuk menemukan logika dominan yang terdapat di dalam teks; dan ketiga menginterpretasi asumsi-asumsi lain terhadap pemaknaan pelacur untuk kemudian diputarbalikkan dari struktur hierarkis oposisi biner, yaitu menemukan invensi makna pelacur. Penelitian ini menemukan bahwa ada tujuh oposisi biner pelacur yaitu laki-laki, pekerja pagi/siang, dokter, guru, istri pejabat, pembunuh, dan pembentuk rumah tangga harmonis. Adapun makna pelacur menemukan invensinya sebagai orang yang bertanggung jawab terhadap keluarga, penolong/pahlawan, jujur, dan mereka adalah korban.
\end{abstract}

Kata kunci: pelacur, dekonstruksi, makna, cerpen 


\section{PENDAHULUAN}

Pelacur tidak dianggap sebagai pekerjaan normal. Profesi ini selalu sangat bertentangan dengan norma-norma yang ada pada masyarakat, terutama norma susila yang didasarkan pada ajaran agama. Bagi masyarakat yang moralis, pelacur dianggap sebagai pekerjaan yang kotor, hina, dan nista. Di Indonesia, bahkan pelacur dianggap sebagai sundal. Jalan hidup menjadi seorang pelacur cenderung dianggap sebagai pilihan yang terpaksa, terjerumus, atau terjebak. Pilihan yang bukan menjadi cita-cita setiap manusia. Banyak faktor tentunya yang melandasi mengapa pilihan menjadi seorang pelacur itu dilakoni. Hal ini diungkapkan oleh Seno Gumira Ajidarma (SGA) dalam salah satu cerpen yang berjudul Pelacur (2005). Tanggapan tokoh "aku" dalam cerpen itu seolah memafhumkan bahwa perempuan melacur karena terhimpit masalah ekonomi, menerima janji manis soal pekerjaan dan penghasilan, diperkosa calo yang membawanya dari kampung, yang justru dianggap sebagai keklisean.

Dalam sebuah penelitian tentang pelacuran di Jawa yang dikaitkan dengan kebudayaan, pelacuran terjadi karena ada kaitan dengan konteks kebudayaan (Worcester, 2002). Praktik pelacuran yang berkorelasi dengan kebudayaan menjadi hal yang lumrah dan bukan menjadi hal yang dipertentangkan karena dapat memberi keuntungan ekonomi bagi masyarakat dan pemerintah setempat. Selain penelitian, juga banyak ditemukan karya sastra yang mengangkat tema tentang kehidupan malam, terutama tentang pelacuran. Satu contoh karya sastra yang mampu dengan baik menghubungkan antara pelacuran dengan kebudayaan dapat ditemukan dalam Trilogi Ronggeng Dukuh Paruk (2011) karya Ahmad Tohari. Dalam novel tersebut, identitas ronggeng juga mendapat stigma negatif seperti halnya pelacur meskipun hal tersebut inheren dalam kebudayaan.

Sementara itu, khazanah sastra Indonesia lainnya yang mengangkat tema tentang pelacuran dapat ditemukan pada, misalnya Sumpah WTS (1983) puisi karya F. Rahardi, serta puisi-puisi W. S. Rendra seperti Bersatulah Pelacur-Pelacur Kota Jakarta! (2013). Dalam puisi Nyanyian Angsa (2013), Rendra bahkan melukiskan
Maria Zaitun, seorang pelacur yang justru menjadi kekasih Tuhan, yang dikontraskannya dengan kaum agamawan yang menjauhkan diri daripadanya. Dalam Nyanyian Angsa, Rendra ingin menunjukkan bahwa seorang agamawan pun terkadang melakukan stigma terhadap pelacur. Dalam puisi-puisi mengenai pelacuran ini, penyair hendak memperlihatkan soal penderitaan kemanusiaan yang jauh dialami oleh pelacur. Muhidin M. Dahlan menulis novel yang berjudul Tuhan, Izinkan Aku Menjadi Pelacur (2005) yang bercerita tentang tokoh Muslimah yang memilih identitas dirinya sebagai pelacur dan berhasil keluar dari tekanan-tekanan sosial. Novel Muhidin ini telah dianalisis oleh Mustika (2014) dalam tesis S2-nya di Universitas Gadjah Mada perihal eksistensi seorang pelacur dalam melampaui tekanan-tekanan sosialnya.

Dari beberapa karya sastra tersebut, penulis berasumsi ada upaya pengarang untuk melihat sisi lain kehidupan para pelacur, terutama dalam cara pandang pelacur itu sendiri di dalam karya mereka. Salah satu pengarang yang mengangkat tema kehidupan malam beserta orang-orang yang ada di dalamnya secara mendetail dapat ditemukan dalam karya Seno Gumira Ajidarma (SGA) yang terkumpul dalam kumpulan cerpen Atas Nama Malam (ANM) (1999).

Kumpulan cerpen ANM pertama kali diterbitkan oleh Gramedia pada tahun 1999 dan telah mengalami cetak ulang. Cerpen-cerpen yang ditulis oleh SGA dalam ANM memiliki rentang waktu penulisan yang berbeda-beda. Bagian pertama kumpulan cerpen ini_yang terdiri dari beberapa potongan cerita_ditulis pada bulan Januari tahun 1990 dan diterbitkan di majalah Matra. Pada bagian kedua, seluruh cerpen terbit pada tahun 90-an. Pelajaran Mengarang (PM) terbit di koran Kompas pada tahun 1992 dan masuk dalam cerpen pilihan Kompas tahun 1993. Cerpen Ratih terbit di harian Suara Pembaruan tahun 1992, Dewi di majalah Belanja tahun 1997, Max terbit di tabloid Aura tahun 1997, Lonely Lover Symphony (LLS) terbit di majalah Warta Bumiputra tahun 1996, Ibu Tidak di Rumah (ITR) terbit di majalah Keluarga Gaya tahun 1997, Bulan di Atas Kampung (BAK) terbit di harian Kompas tahun 1994, Catatan Sepanjang Malam 
(CSM) diterbitkan di majalah Variasi Putra Indonesia tahun 1983, Episode terbit di majalah Matra tahun 1997, dan Bis Malam juga terbit di majalah Matra tahun 1993.

SGA sepertinya ingin mengajak kita (pembaca) untuk masuk menyelami bagaimana persoalan-persoalan yang dihadapi pelacur dalam menjalankan profesinya. SGA juga seperti mengajak pembacanya untuk menyelami kehidupan pelacur yang juga sebagai manusia dengan segala problematik kehidupan layaknya profesi manusia lainnya. Tujuannya, agar pelacur tidak lagi dilihat secara hitam-putih, dilihat dengan kaca mata normatif belaka, dan yang selalu beroposisi dengan identitas pekerja lain. Pelacur pada pekerjaan yang negatif, kotor, hina, dan lain sebagainya, sedangkan profesi lain pada pekerjaan yang positif, bersih, mulia, dan sebagainya.

Kumpulan cerpen ANM secara keseluruhan bercerita tentang kehidupan malam orang-orang yang ada di kota besar, terutama kehidupan para pelacur sekalipun tidak semua secara eksplisit diceritakan. Kumpulan cerpen ANM ini terdiri dari dua bagian. Bagian pertama berjudul Suatu Malam, Aku Jatuh Cinta dan bagian kedua berjudul Suatu Malam Aku Bercerita. Bagian yang pertama ini terdiri dari berbagai potongan cerita. Ada 14 judul di dalamnya, antara lain Senja dan Sajak Cinta, Lipstik, Bibir, Suara-suara, Pembunuhan, Pelacur, Surat, Mereka Datang dan Pergi, Ia Menangis, Hidup Terasa Panjang, Pertemuan yang Batal, Orang-orang Sakit Kelamin, Profil Pembunuh, dan Senja, Penutupan. Keempat belas cerita ini merupakan satu kesatuan cerita dengan tokoh utamanya si Aku yang bekerja sebagai bartender pada sebuah pub di Jakarta dan sedang jatuh cinta dengan seorang pelacur. Sementara itu, bagian kedua terdiri dari 10 cerpen, yaitu Pelajaran Mengarang, Ratih, Dewi, Max, Lonely Lover Symphony, Ibu Tidak di Rumah, Bulan di Atas Kampung, Catatan Sepanjang Malam, Episode, dan Bis Malam. Pada bagian kedua ini, sepuluh cerpen tidak memiliki satu kesatuan cerita dengan tokoh-tokoh yang berbeda. Akan tetapi, cerita-cerita tersebut dapat dihubungkan satu dengan yang lain karena penulis akan melakukan identifikasi oposisi-oposisi biner yang ada di dalam teks.
Kerja identifikasi antara cerpen satu dan yang lain ini digunakan dengan asumsi bahwa di dalam kumpulan cerpen itu terdapat oposisi biner yang dapat dikaitkan, misalnya oposisi biner antara pelacur (Ibunya Sandra, Mami) dengan tokoh Ibu Guru Tati yang terdapat dalam cerpen PM dan pelacur (Ibu Sandra dalam PM) dengan orang tua Ratih (dalam cerpen Ratih) dan tokoh Dewi (dalam cerpen Dewi). Oposisi ini menunjukkan makna secara hierarkis yang menempatkan satu posisi/identitas yang tersubordinat, yaitu pelacur.

Ada dua identitas profesi yang beroposisi di dalam cerpen PM ini yaitu guru dan pelacur. Guru adalah tokoh Ibu Tati dan pelacur adalah tokoh Ibu Sandra dan Mami. Secara hierarkis, profesi guru akan dianggap sebagai profesi yang mulia, baik, dan sebagai pahlawan, sedangkan pelacur sebagai yang hina, tidak baik, dan hal negatif lainnya. Profesi guru menempatkan posisi yang eksklusif daripada profesi pelacur. Akan tetapi di dalam cerpen tersebut, struktur makna yang beroposisi itu mengalami pembalikkan. Guru yang bermakna baik dan pahlawan justru menjadi dibenci atau tidak disukai karena meminta mengarang sesuatu yang tidak sesuai dengan kenyataan hidup Sandra. Justru Ibunya dan Mami yang pelacur bermakna sebagai manusia yang baik, bertanggung jawab dan sebagai pahlawan bagi Sandra karena menjaga, melindungi, dan menyekolahkannya. Sandra bisa saja anak yang ditinggal bapaknya, atau bapaknya yang tidak diketahui siapa karena Ibunya yang pelacur. Berhasilnya Sandra dapat bersekolah sampai kelas 4 SD menandakan bahwa Ibu Sandra justru bertanggung jawab terhadap anaknya dan mengasihinya. Perubahan makna pelacur dalam cerpen PM ini mengalami dekonstruksi melalui oposisi biner yang terdapat di dalam teks PM.

Ada beberapa oposisi yang dapat dikaitkan dari satu cerpen ke cerpen lain terkait makna pelacur sebagai benang merah di dalam kumpulan cerpen ANM. Oleh karena itu, penulis akan memfokuskan pada permasalahan bagaimana makna pelacur ini telah mengalami dekonstruksi sehingga pelacur tidak lagi bermakna secara stereotip yang melulu hina, kotor, tidak baik, dan sebagainya; melainkan menemukan invensi makna yang baru terhadap teks-teks cerpen. Selisik kumpulan cer- 
pen ANM ini akan menggunakan perangkat teori dekonstruksi Derrida yang akan penulis jelaskan dalam kerangka teoritis.

Penelitian sebelumnya yang menggunakan perangkat teori dekonstruksi Derrida dengan melihat aspek tokoh pelacur adalah tesis Pratiwi yang berjudul Dekonstruksi Pelacur dalam Novel Chrysan Karya Hapie Joseph Aloysia (Pratiwi, 2014). Penelitian ini lebih menitikberatkan pada tokoh utama dalam penggapaian akan medan makna yang berbeda dari yang dilekatkan secara normatif terhadap dirinya. Novel tersebut menurut Pratiwi mendekonstruksi dirinya sendiri dengan mengembalikan usaha penggapaian tokoh-tokohnya ke dunia nyata. Penelitian Pratiwi ini tidak melihat pada persoalan makna normatif itu terbentuk sehingga menempatkan posisi pelacur secara hierarki lebih rendah dari pada posisi identitas lain sebagai yang istimewa. Oleh karena itu, penelitian penulis lebih menekankan pada aspek pemaknaan pelacur yang terbentuk secara hierarkis dari satu cerpen ke cerpen yang lain terhadap profesi yang ada di luarnya, lalu mengalami pembalikkan makna hingga menemukan maknanya yang baru.

Kumpulan cerpen ANM sudah diteliti dengan pendekatan yang berbeda, misalnya skripsi Ariska (2015) yang berjudul Konflik Batin Tokoh Utama dalam Kumpulan Cerpen Atas Nama Malam Karya Seno Gumira Ajidarma dengan pendekatan psikoanalisis Freud, sementara selisik Hesty (2016) cukup unik dengan melihat penjenamaan (merek) yang terdapat dalam cerpen yang berjudul Eksistensi Merek dalam Antologi Cerita Pendek Atas Nama Malam Karya Seno Gumira Ajidarma dengan pendekatan semiotika. Penulis sendiri belum menemukan selisik dengan pendekatan dekonstruksi Derrida terhadap kumpulan cerpen ANM. Oleh karena itu, penelitian ini akan menjadi temuan baru terutama terkait invensi pemaknaan pelacur setelah mengalami dekonstruksi terhadap makna pelacur sebelumnya.

Dekonstruksi merupakan suatu teori yang berangkat dari negasi akan kepastian dan kebenaran makna yang dikukuhkan oleh Saussure sebagai strukturalisme. Teori ini membongkar berbagai asumsi yang tersembunyi di dalam linguistik struktural (Lubis dalam Situmeang, 2016, 140-141). Kritik Derrida terhadap strukturalisme Saussure adalah model berpikir oposisi biner sebagai struktur yang stabil, bahwa makna yang benar hanya dapat tercipta dari kestabilan tersebut yaitu antara penanda dan petanda. Sarup $(2003,55)$ mengatakan bahwa makna tidak akan pernah sama dari satu konteks ke konteks yang lain; petanda akan selalu diubah oleh pelbagai macam mata rantai penanda yang menjeratnya.

Pemberian makna dari hasil pembacaan sebenarnya bukan kerja dekonstruksi. Dekonstruksi ingin mengemukakan kemustahilan dari produksi makna pada teks. Derrida $(1976,158)$ mengatakan bahwa "there is no outside-text" (tidak ada makna di luar teks). Dekonstruksi selalu dilakukan dari dalam teks.

The movements of deconstruction do not destroy structures from the outside. They are not possible and effective, nor can they take accurate aim, except by inhabiting those structures. Inhabiting them in a certain way, because one always inhabits, and all the more when one does not suspect it. Operating necessarily from the inside, borrowing all the strategic and economic resources of subversion from the old structure, borrowing them structurally, that is to say without being able to isolate their elements and atoms, the enterprise of deconstruction always in a certain way falls prey to its own work (Derrida, 1976, 24).

Asumsi teoretis Derrida ini senantiasa mencurigai bahwa dalam teks selalu ada inkonsistensi, kontradiksi, dan ketidaktepatan. Tujuan dari kerja dekonstruksi ini adalah memikirkan kembali atas segala sesuatu yang diterima selama ini yaitu makna tunggal antara penanda dan petanda seperti yang terdapat dalam pemikiran strukturalisme Saussure dan Levi Strauss. Dekonstruksi membongkar makna teks yang tunggal dan memberi ruang untuk munculnya makna-makna baru (Caputo, 1986, 9).

Menurut Derrida (Faruk, 2012, 209), makna tidak langsung hadir dalam sebuah tanda. Makna suatu tanda adalah apa yang bukan tanda itu sendiri, dan makna itu selalu, dalam pengertian tertentu, tidak hadir darinya. Makna tersebar dan terserak di sepanjang rantai penanda keseluruhan. Makna tidak dapat dipakukan, ia tidak pernah hadir dalam hanya satu tanda, tetapi lebih sebagai 
sejenis kelap-kelip yang konstan dari kehadiran dan ketidakhadiran sekaligus.

Pembacaan dekonstruksi (Barry, 2010, 82) merupakan penyingkapan dimensi tidak sadar teks, bukan dimensi sadarnya. Semua hal yang terbuka dan jelas tidak menjadi perhatian dan bahkan diabaikan saja sebab dekonstruksi justru akan menyingkap hal yang tersembunyi, kontradiktif, dan mengandung inkonsistensi internal dalam teks. Derrida tidak menyepakati adanya makna tunggal (logos). Selalu ada yang dibutuhkan dari sesuatu yang bukan bagi dirinya (Al-Fayyadl, 2011, 106-107). Dari sini kemudian lahir konsep trace bahwa makna merupakan jejak-jejak makna sebelumnya (Imron, 2015, 73).

Al-Fayyadl $(2011,82)$ mengatakan bahwa dekonstruksi menggugat modus pemaknaan yang terpusat dan cenderung bulat seperti yang mungkin diinginkan oleh teks atau yang dengan sengaja dimunculkan secara terang-benderang oleh hubungan logis dari teks tersebut. Dekonstruksi, secara garis besar, adalah cara untuk membawa kontradiksi-kontradiksi yang bersembunyi di balik konsep-konsep yang kita pahami selama ini dan keyakinan yang melekat pada diri ini ke hadapan kita. Dekonstruksi adalah cara membaca teks sebagai strategi. Pembacaan dekonstruktif hanya ingin mencari ketidakutuhan atau kegagalan tiap upaya teks menutup diri dengan makna atau kebenaran tunggal. Dia hanya ingin menumbangkan susunan hierarki yang menstrukturkan teks (Norris, 2006, 14).

Pembacaan cermat dekonstruktif itu-sesudah menginterogasi teksnya-menghancurkan pertahanannya, dan menunjukkan bahwa seperangkat oposisi berpasangan ditemukan di dalamnya. Oposisi itu tersusun secara hierarkis dengan menempatkan salah satu pasang sebagai yang istimewa. Dekonstruktor kemudian menunjukkan bahwa identitas yang istimewa itu tergantung pada pengeksklusiannya atas yang lain dan menunjukkan bahwa keutamaan justru terletak pada yang justru disubordinasikan (Faruk, 2012, 217).

Oposisi biner berperan penting dalam metafisika untuk menciptakan kestabilan struktur. Salah satu unsur harus menjadi pusat, sedangkan unsur lain berstatus sebagai pelengkap yang menegaskan pusat tersebut. Dalam karya sastra, misalnya novel atau cerpen, oposisi biner sering menjadi kerangka yang menopang struktur cerita. Ada tokoh antagonis-protagonis, kebaikankejahatan, tuan rumah-tamu, dan sebagainya. Berbagai oposisi biner dalam teks yang dibaca dapat menjadi fokus pembacaan dekonstruksi (Ungkang, 2013, 33).

Selain pengungkapan oposisi biner teks, proses dekonstruksi juga melalui proses rekonstruksi teks. Perspektif dekonstruksi Derrida tidak bertujuan untuk mengembalikan teks kepada yang asli atau kepada kondisi asal, tetapi "what deconstruction attempts to do is to articulate theoften hidden or repressed-conditions according to which it is possible for any structure to be constituted in the first place" (Bradley, 2008, 43). Rekonstruksi ini merupakan bentuk praksis untuk mendekonstruksi teks dari dalam.

Melalui teori dekonstruksi, pemaknaan tidak lagi tunggal. Teks-teks yang terdapat dalam cerpen terkait pemaknaan pelacur dalam dekonstruksi menjadi tidak stabil. Identitas pelacur dalam cerpen tidak dapat lagi menempatkan pada posisi yang tersubordinasi karena berbagai penanda-penanda lain dalam teks yang memiliki potensi untuk mendekonstruksi makna yang stabil tersebut. Struktur hierarki yang membentuk pemaknaan pelacur dalam konteksnya yang tunggal akan dihancurkan melalui teori dekonstruksi hingga menghadirkan maknanya yang berbeda.

\section{METODE}

Penelitian ini menggunakan metode dekonstruksi Derrida terhadap data penelitian berupa kumpulan cerpen ANM. Metode dekonstruksi merupakan metode pembacaan cermat sebuah teks. Metode dekonstruksi ini dapat dikatakan sebagai metode hermeneutik yaitu metode penafsiran terhadap teks yang dalam hal ini adalah teks sastra. Di dalam Positions, Derrida (1998, 41-42) mengatakan bahwa strategi dekonstruksi sebagai tulisan ganda atau pembacaan ganda beroperasi dalam dua langkah sekaligus: memahami secara teliti sebuah teks dari dalam teks itu sendiri dan merekonstruksi maksud pengarang serta kandungan teks, kemudian mendekonstruksi makna sentral dari sebuah teks. Langkah atau 
strategi yang dilakukan dengan metode ini adalah melakukan pembacaan cermat seluruh cerpen, kemudian mengklasifikasikan oposisi-oposisi biner terhadap objek formal dalam penelitian ini yaitu pelacur. Dalam hal ini, tokoh pelacur dan berbagai penandanya akan diklasifikasi menurut pasangan-pasangannya seperti pelacur dengan laki-laki yang menjadi tamu, pelacur dengan perempuan lain (seperti istri pejabat), pelacur dengan profesi yang lain (seperti guru), dan sebagainya.

Strategi kedua dari metode dekonstruksi adalah rekonstruksi teks. Rekonstruksi merupakan cara untuk mengungkapkan logika "dominan" yang ada di dalam teks. Cerpen-cerpen ANM akan direkonstruksi atau mengalami penceritaan ulang sehingga akan terungkap kondisi teks baik struktural maupun logika yang bekerja di dalamnya, terutama terkait dengan hierarki makna pelacur. Dalam proses rekonstruksi tersebut, juga dikemukakan konteks asli dan konteks resepsi dominan atas teks tersebut (Bradley, 2008, 3). Konteks resepsi dominan perlu dikemukakan karena cara suatu teks dibaca juga dipengaruhi oleh apa yang disebut Culler $(2001,139)$ sebagai "common procedures of reading".

Strategi ketiga adalah dekonstruksi teks. Setelah menemukan teks-teks yang beroposisi secara hierarkis tersebut (ditemukan melalui rekonstruksi teks) dan logika dominan yang terdapat di dalamnya, akan dilakukan langkah analisis dan interpretasi yang mendalam sehingga menemukan pemaknaan yang baru. Proses analisis ini merupakan cara untuk menunjukkan "logika lain" atau unsur lain yang tidak dapat dikembalikan pada relasi hierarkis sebelumnya.

\section{TEMUAN DAN DISKUSI}

\section{Pelacur dan Berbagai Oposisinya}

Kumpulan cerpen ANM secara garis besar menceritakan berbagai peristiwa mengenai orangorang yang hidup dalam dunia malam, secara khusus kaum pelacur. Meskipun secara eksplisit beberapa cerpen, seperti Ratih, Dewi, Max, Lonely Lover Symphony, Ibu Tidak di Rumah, dan Bis Malam tidak bercerita tentang pelacur, akan tetapi peristiwa dalam cerpen itu juga dapat menjadi penanda-penanda yang lain bagi penanda pelacur. Artinya, kehadiran cerpen-cerpen tersebut juga akan memberi penegasan pada pemaknaan akan pelacur pada cerpen-cerpen yang secara eksplisit bercerita tentangnya. Makna pada satu cerpen dalam perspektif dekonstruktif tidak hadir secara stabil, cerpen tersebut saling berkaitan makna satu dengan yang lainnya. Makna yang satu ada karena makna cerpen-cerpen lain sebagai relasi penanda. Hal ini kemudian menjadi strategi dalam dekonstruksi untuk menemukan hal-hal yang menjadi oposisi-oposisi terhadap identitas pelacur yang mana hierarki makna itu terbentuk.

Pijakan pertama dalam asumsi pembacaan Dekonstruksi Derrida adalah bahasa yang secara tidak terpisahkan ditandai oleh ketidakstabilan dan ketakberhinggaan makna. Melalui asumsi dasar ini, keseluruhan cerpen dibahas, baik terhadap cerpen itu sendiri maupun dengan relasi cerpen yang lain. Makna atau penanda dalam satu cerpen akan ditunda untuk melihat makna-makna/penanda lain di dalam cerpen yang lainnya. Suatu penanda, bagi Derrida, hanya menunjuk kepada penanda-penanda lain.

Untuk dapat melihat kestabilan struktur teks yang terbentuk secara hierarkis di dalam cerpen, penulis akan mengklasifikasikan hal-hal apa saja yang saling beroposisi di dalamnya. Secara spesifik, penulis hanya akan menemukan oposisi-oposisi dari identitas pelacur yang membuat makna pelacur mendapatkan posisi yang terstigmatisasi, seperti kotor, hina, sampah, dan sebagainya. Oposisi biner yang ada di dalam cerpen ini penting dilakukan karena menjadi penopang dalam struktur cerita dan penemuan akan oposisi biner tersebut menjadi fokus dalam pembacaan dekonstruksi.

Pada bagian pertama kumpulan cerpen ANM, yang terdiri dari berbagai potongan cerita dengan satu tokoh Aku sebagai sentralnya, terdapat beberapa klasifikasi oposisi biner yang ditemukan. Sebagai catatan, tidak semua potongan cerita tersebut akan diklasifikasikan oposisi binernya. Oposisi biner yang diklasifikasi adalah yang berkaitan dengan pemaknaan terhadap pelacur. Oposisi biner di dalam cerpen ini juga bisa secara eksplisit maupun implisit. Berikut tabel oposisi biner yang terdapat pada bagian pertama. 
Bagian kedua kumpulan cerpen ANM merupakan cerpen-cerpen yang terpisah karena tokoh-tokohnya yang berbeda. Akan tetapi, cerpen Episode masih memiliki hubungan dengan potongan cerita yang ada pada bagian pertama. Penandanya adalah tokoh Elok yang adalah pelacur sekaligus waitress di sebuah bar. Sama seperti halnya pada bagian pertama cerpen, pada bagian kedua ini akan diklasifikasikan oposisi biner yang terdapat dalam tiap-tiap cerpen baik yang eksplisit maupun yang implisit. Oposisi yang implisit hanya menyebutkan satuan yang terdapat dalam cerpen dan mengimplikasikan satuan yang lainnya.

Tabel 1. Oposisi Biner Bagian Pertama: Suatu Malam, Aku Jatuh Cinta

\begin{tabular}{|c|c|c|}
\hline No. & Cerpen & Oposisi Biner \\
\hline 1 & Senja dan Sajak Cinta & laki-laki x wanita; senja x malam \\
\hline 2 & Lipstik & $\begin{array}{l}\text { Aku x penyanyi bar; pekerja x pengemis; } \\
\text { laki-laki x wanita; ibukota x kota lain; siang } \\
\text { x malam }\end{array}$ \\
\hline 3 & Bibir & Penyanyi bar/wanita $\mathrm{x}$ tamu \\
\hline 4 & Suara-suara & $\begin{array}{l}\text { Bartender x wartawan/akuntan/manajer pema- } \\
\text { saran/ insinyur pertambangan; pekerja malam } \\
\text { x pekerja pagi }\end{array}$ \\
\hline 5 & Pembunuhan & $\begin{array}{l}\text { Pembunuh } \mathrm{x} \text { orang terbunuh; pekerja malam } \\
\mathrm{x} \text { pekerja siang; perusak rumah tangga x pem- } \\
\text { bentuk rumah tangga harmonis }\end{array}$ \\
\hline 6 & Pelacur & $\begin{array}{l}\text { Orang pagi } \mathrm{x} \text { orang malam; bukan pelacur } \mathrm{x} \\
\text { pelacur }\end{array}$ \\
\hline 7 & Surat & $\begin{array}{l}\text { Aku x kekasih; orang berarti/pahlawan x } \\
\text { orang tidak berarti/bukan pahlawan }\end{array}$ \\
\hline 8 & Mereka Datang dan pergi & Bos x karyawan \\
\hline 9 & Ia Menangis & Aku x penyanyi bar \\
\hline 10 & Hidup Terasa Panjang & $\begin{array}{l}\text { Hidup x mati; laki-laki x wanita/janda tua; } \\
\text { janda tua x wanita muda }\end{array}$ \\
\hline 11 & Pertemuan yang Batal & $\begin{array}{l}\text { Bos x karyawan; istri kedua x istri pertama; } \\
\text { bos x penyanyi; penyanyi bar x penyanyi } \\
\text { artis; penari telanjang x penari seni }\end{array}$ \\
\hline 12 & Orang-orang Sakit Kelamin & pelacur $\mathrm{x}$ dokter; berpenyakit $\mathrm{x}$ sehat \\
\hline 13 & Profil Pembunuh & $\begin{array}{l}\text { Pemijat x tamu; kesepian x keramaian; } \\
\text { pekerja malam x pekerja kantoran; gadis bar } \\
\text { x tamu }\end{array}$ \\
\hline 14 & Senja, Penutupan & Orang kantoran $\mathrm{x}$ pekerja malam \\
\hline
\end{tabular}

Sumber: Diperoleh dari data primer 
Tabel 2. Oposisi Biner Bagian Kedua: Suatu Malam Aku Bercerita

\begin{tabular}{lll} 
No. & Cerpen & Oposisi Biner \\
1 & Pelajaran Mengarang & pelacur x guru; anak pelacur x anak yang lain \\
\hline 2 & Ratih & $\begin{array}{l}\text { mayat x orang hidup; keluarga pejabat x keluarga pelacur; anak } \\
\text { keluarga pejabat } \mathrm{x} \text { anak pelacur }\end{array}$ \\
\hline 3 & Dewi & istri x suami; perempuan x laki-laki \\
\hline 4 & Max & istri x suami; wanita x laki-laki \\
\hline 6 & Lonely Lover Symphony & perempuan x laki-laki \\
\hline 7 & Bulan di Atas Kampung & $\begin{array}{l}\text { Anak pelacur x bukan anak pelacur; penari ular x penari seni; } \\
\text { ibu x bapak; ibu pelacur x ibu yang lain }\end{array}$ \\
\hline 8 & Catatan Sepanjang Malam & $\begin{array}{l}\text { Wanita malam x wanita siang; wanita bertato x tidak bertato; } \\
\text { anak pelacur x bukan anak pelacur }\end{array}$ \\
\hline 9 & Episode & $\begin{array}{l}\text { Bukan orang penting x orang penting; boleh dibunuh x tidak } \\
\text { boleh dibunuh }\end{array}$ \\
\hline 10 & Bis Malam & perempuan x laki-laki; pelacur x bukan pelacur \\
\hline & & Sumber: Diperoleh dari data primer
\end{tabular}

Keseluruhan rangkaian oposisi biner di tiap-tiap cerpen itu memiliki hubungan satu dengan yang lainnya. Utamanya terkait dengan gender dan nilai identitas, seperti laki-laki dan perempuan; pekerja malam dan pekerja pagi/ siang; pelacur dan bukan pelacur; dan beberapa hal lainnya yang tersusun secara hierarkis. Secara dekonstruksi, pasangan-pasangan oposisi ini memiliki keterhubungan sebagai penanda-penanda yang membentuk satu sama lain. Oleh karena itu, pengklasifikasian pada tahap berikut ini merupakan tahap untuk dapat melakukan strategi dekonstruksi, terutama dalam melihat pemaknaan pelacur.

Tabel 3. Oposisi Biner Antarcerpen

\begin{tabular}{lll} 
No. & Oposisi Biner Antarcerpen \\
1 & laki-laki & wanita \\
\hline 2 & pekerja pagi/siang & pekerja malam \\
\hline 3 & Pembunuh & boleh dibunuh \\
\hline 4 & $\begin{array}{l}\text { pembentuk rumah } \\
\text { tangga harmonis }\end{array}$ & $\begin{array}{l}\text { perusak rumah } \\
\text { tangga }\end{array}$ \\
\hline 5 & Dokter & pelacur \\
\hline 6 & Guru & pelacur \\
\hline 7 & istri pejabat & pelacur \\
\hline
\end{tabular}

Sumber: Diperoleh dari data primer
Oposisi biner antarcerpen ini terhubung satu penanda di dalam cerpen dengan penanda-penanda yang ada di dalam cerpen yang lain. Penanda pelacur yang terdapat di dalam potongan cerita di bagian pertama dengan beberapa cerpen yang terdapat di dalam bagian kedua dihubungkan dengan cerpen-cerpen yang secara eksplisit tidak menceritakan tentang kehidupan pelacur. Oleh karena itu, penanda yang ada di dalam cerpen yang tidak bercerita tentang kehidupan pelacur dijadikan penanda oposisi dari pelacur, sebagai perempuan, dan para pekerja malam. Begitu pula dengan penandanya sebagai perusak rumah tangga yang dihubungkan dengan penanda-penanda oposisinya yang terdapat di dalam cerpen lain. Dengan menghubungan penanda-penanda antarcerpen ini maka logika dominan yang bermain secara hierarkis dapat diketahui.

\section{REKONSTRUKSI TEKS: LOGIKA DOMINAN DALAM TEKS}

Secara keseluruhan, cerpen-cerpen yang terdapat dalam ANM ini memiliki oposisi secara garis besar dengan logika dominannya, seperti orangorang yang bekerja malam atau yang disebut sebagai pekerja malam dengan orang-orang yang bekerja pada pagi dan siang hari. Dalam ANM, 
SGA banyak menceritakan tentang kehidupan malam dengan orang-orang yang beraktivitas di dalamnya. Dari keseluruhan cerpen, hanya ada lima cerpen yang tidak menggambarkan kehidupan malam secara eksplisit, yaitu cerpen Ratih, Dewi, Max, Lonely Lover Symphony, dan Ibu Tidak di Rumah. Dari kelima cerpen inilah yang penulis temukan oposisi dari para pekerja malam atau secara spesifik para pelacur.

Pada bagian pertama ANM, bercerita tentang tokoh Aku sebagai pusat penceritaan yang merantau dari kampung halamannya dan bekerja sebagai bartender pada sebuah kafe yang hanya buka pada malam hari. Di dalam kehidupannya sepanjang malam sebagai bartender, si Aku jatuh cinta pada seorang penyanyi kafe dan ia melihat berbagai peristiwa dan perilaku orang-orang yang bekerja pada malam hari dan terutama orang-orang yang ada di bar atau diskotik. Semua orang-orang yang bekerja malam dan para pengunjung bar/kafe menunjukkan seolah-olah mereka senang melakukan aktivitasnya.

Potongan-potongan cerita pada bagian pertama ini menemukan beberapa oposisi baik secara implisit maupun eksplisit. Secara eksplisit, beberapa potongan cerpen menandakan adanya oposisi laki-laki dan wanita seperti yang terdapat dalam potongan Senja dan Sajak Cinta, Lipstik, Bibir, Pembunuhan, Pelacur, Surat, Merdeka Datang dan Pergi, Ia Menangis, Hidup Terasa Panjang, Pertemuan yang Batal, dan Profil Pembunuh. Secara implisit, sebenarnya oposisi laki-laki dan wanita itu juga bisa ditemukan dalan potongan yang lain. Oposisi ini menempatkan hierarki wanita pada posisi identitas yang lebih rendah daripada laki-laki. Para wanita yang terdapat pada setiap potongan cerita umumnya bekerja sebagai karyawan bar, penyanyi bar, penari telanjang, waitress, dan pemijat. Kesemuanya pada posisi untuk menyenangkan para tamu bar yang datang. Tamu dan bos yang khususnya laki-laki menempatkan posisi mereka yang mesti dilayani dan dipatuhi. Bos dan tamu lebih tinggi posisinya karena berkuasa atas posisi karyawan bar, penyanyi bar, penari telanjang, waitress, dan pemijat. Di dalam potongan cerpen, penentuan diterimanya penyanyi bar bukan saja berdasarkan suaranya yang bagus, melainkan seberapa pesonanya menarik para tamu.
"Waktu memegang mikrofon, aku sudah yakin ia akan diterima. Ia sangat mengesankan. Bukan hanya suaranya yang bagus. Atau caranya membawakan lagu yang menarik. Aku merasa ada semacam pesona padanya yang membuat orang mudah jatuh cinta. Dan akupun segera tahu, bukan hanya aku yang jatuh cinta padanya malam itu." (Ajidarma, 2005, 9)

Tamu ditempatkan pada posisi yang lebih tinggi dalam relasinya karena menjadi orang yang harus disenangkan dan dipuaskan. Mereka memiliki hak-hak yang distimewakan. Para penyanyi bar, penari telanjang, pembawa pesanan (waitress), bar-girl, dan tukang pijat adalah orang-orang yang harus memberi kesenangan dan kepuasan kepada tamu. Kebahagiaan para tamu ditentukan oleh mereka dan tidak peduli kondisi mereka. Masalah hidup, beban, dan sebagainyayang dialami para wanita itu - tidak bisa dijadikan alasan untuk tidak membahagiakan para tamu. Para wanita yang bekerja sebagai massage-girl (pemijat) dalam potongan cerita Lipstik bahkan sekaligus menjadi pemuas nafsu tamu dan paling rendah posisinya (Ajidarma, 2005, 9). Sementara itu, posisi pemijat di potongan cerita Bibir adalah hal yang paling penting dibandingkan bar dan segala aktivitasnya. Para tukang pijat tidak memerlukan kecantikan atau kepandaian memijat, mereka cukup memberikan pelepasan hasrat libidinal para pengunjung setelah penat bekerja (Ajidarma, 2005, 10).

Oleh karena posisi wanita-wanita tersebut lebih rendah dibandingkan para tamu yang umumnya laki-laki maka penanda-penanda yang buruk juga menjadi bagian dari identitas mereka. Pada potongan cerita dan cerpen-cerpen, penanda buruk dilekatkan pada identitas mereka, seperti orang yang layak dibunuh, perusak rumah tangga, layak dicampakkan karena sudah tua, istri kedua, berpenyakit kelamin, bertato, suka berkelahi, dan cuma menjadi penghilang rasa haus. Pada cerpen Pembunuh, ada peristiwa pembunuhan pada seorang wanita pemijat dan wanita remaja karena dianggap sebagai perusak rumah tangga. Tidak ada kejelasan tentang peristiwa mengapa pelacur itu dianggap sebagai perusak rumah tangga. Potongan cerpen ini hanya penceritaan dari tokoh aku yang menggambarkan tentang peristiwa pembunuhan yang dilakukan oleh 
seorang wanita sebagai yang sensasional pada dirinya. Bagi wanita berpistol itu, wanita remaja itulah yang menjadi biang keladi rusaknya rumah tangga mereka. Oleh karena itu, wanita remaja itu layak untuk dilenyapkan nyawanya. Sementara itu, suami atau pihak laki-laki yang juga terlibat dalam kondisi rumah tangga yang rusak tidak mendapatkan sanksi apa-apa.

"Wanita itu mengeluarkan pistol dari tasnya. Ia membuang tas itu dan mengacungkan pistol itu dengan kedua tangannya. Dan ia berteriak, "Rasakanlah ini, perusak rumah tangga orang!"," (Ajidarma, 2005, 19)

Padahal, wanita remaja itu dikatakan oleh tokoh aku sebagai gadis yang masih terlalu kecil untuk mencari uang, terutama sebagai pelacur. Gadis itu seharusnya masih duduk di bangku sekolah dan menikmati masa keremajaannya. Akan tetapi, selalu ada kondisi yang membuat gadis remaja itu akhirnya melakoni pekerjaannya. Peristiwa orang yang layak dibunuh dan mayatnya dibuang juga tergambarkan pada cerpen Ratih. Dalam cerpen itu, tokoh anak bernama Ratih penasaran dengan mayat yang mengapung pada sebuah sungai yang ada di belakang rumahnya. Tidak ada penjelasan tentang dari mana mayat itu berasal dan peristiwa apa yang melatarbelakanginya di dalam cerpen, tetapi ia bisa saja menjadi penanda sebagai orang-orang yang direndahkan identitasnya baik sebagai pekerja malam, pelacur, yang dianggap layak untuk dibunuh.

Beberapa cerpen lain yang juga menandakan bahwa pelacur atau perempuan lain menjadi perusak rumah tangga dapat ditemukan secara implisit dalam cerpen Ibu Tidak di Rumah (ITR), Max, Bulan di Atas Kampung, dan Episode. Cerpen ITR ini bercerita tentang sebuah keluarga mapan dan populer. Kemapanan dan kepopuleran tentu menjadi keinginan setiap orang karena beranggapan kebahagiaan akan diperoleh melalui penanda tersebut. Namun, tidak bagi keluarga itu. Rumah yang mewah dengan perabotan antik justru terlihat sepi dan kehilangan keharmonisannya karena Ibu pergi dari rumah dan belum kembali. Penyebabnya diceritakan oleh sang anak karena ada aib yang disembunyikan oleh Ibu dan Bapaknya dan yang membuat aib itu adalah Bapaknya. Aib itu seperti tidak bisa dimaafkan oleh Ibunya sehingga memutuskan untuk pergi meninggalkan keluarganya. Kepergian Ibunya seperti dendam kepada Bapaknya karena sudah melakukan perselingkuhan (membuat aib keluarga) terlebih dahulu. Perselingkuhan si Bapak dengan wanita lain telah membuat rumah tangga itu menjadi tidak lagi harmonis atau rusak.

Cerpen Max bercerita tentang seorang perempuan yang bernama Martha bekerja sebagai peramal dengan menggunakan permainan kartu. Tamu yang datang umumnya wanita dengan masalah-masalah yang sama seperti akan ditinggal suami dan menikah lagi dengan perempuan lain. Nasib yang menimpa para wanita itu sebenarnya sama dengan nasib yang diderita Martha karena ditinggal suaminya yang bernama Max. Para wanita lain yang menjadi penyebab ditinggalkannya para wanita yang mengadu kepada Martha (termasuk Martha sendiri) menjadi berhak untuk dibunuh karena menjadi pengganggu atau perusak rumah tangga mereka.

\section{"Suami Anda akan kembali.” \\ "Tapi, saya ingin membunuh wanita itu." \\ Martha juga ingin membunuh wanita itu, tentu saja seorang wanita yang lain. Di dalam bola kristal yang ada di depannya, Martha seolah bisa melihat segala kejadian, yang telah membuatnya kehilangan berat badan sebanyak tujuh kilogram. \\ "Saya ingin membunuhnya, saya ingin Ibu mem- bunuhnya untuk saya.” (Ajidarma, 2005, 100)}

Di akhir cerpen Max, wanita yang mengadu kepada Martha bahwa ia telah ditinggal suaminya ternyata adalah Max yang juga adalah suami Martha. Pada kondisi ini, wanita itu dan Martha berada pada posisi yang rendah dibandingkan Max sebagai laki-laki. Posisi yang berada pada hierarki yang rendah ini layak untuk dibunuh karena sudah merusak rumah tangga sebuah keluarga, keluarga wanita itu, dan keluarga Martha. Laki-laki tetap pada posisi lebih tinggi dengan kebebasannya menentukan wanita mana yang menjadi pilihannya dan tidak layak untuk dibunuh. Hal pembunuhan para pelacur/wanita malam yang bernama Lala ini juga ditemukan dalam cerpen Bulan di Atas Kampung (BAK) dan Episode. Cerpen BAK bercerita tentang seorang anak yang bernama Naro memiliki Ibu yang bekerja sebagai penari ular sekaligus pelacur. 
Pulang ke rumah dalam keadaan mabuk, Naro membayangkan keluarganya yang utuh. Hingga Naro teringat bahwa seorang yang dianggapnya sebagai Bapak diketahui melalui jawaban si Ibu sebagai bukan Bapaknya. Di akhir cerita, Naro mengangkat pisau tinggi-tinggi di depan Ibunya yang sedang tidur bersama laki-laki yang tidak dikenalnya. Sementara itu, cerpen Episode bercerita tentang terjadinya peristiwa pembunuhan terhadap seorang wanita yang sangat dikenal oleh tokoh Aku yang bekerja sebagai penulis laporan tentang kematian. Tidak diketahui di dalam cerpen mengapa pelacur itu dibunuh, tetapi pembunuhan terhadap pelacur itu tetap dipandang sebagai sesuatu yang tidak penting oleh tokoh Aku yang laki-laki.

"Aku berhenti menulis. Kalimat ini membuat kematian Lala seolah-olah penting. Padahal, aku tahu, Lala sama sekali bukan orang penting, dan kematiannya pun jangan sampai kelihatan penting. Jangan-jangan sebagian orang berpendapat, kalau wanita seperti Lala ini malah boleh-boleh saja dibunuh." (Ajidarma, 2005, 152)

Selain layak untuk dibunuh, identitas pada posisi rendah ini juga layak untuk dicampakkan atau ditinggalkan. Hal ini dapat dilihat di dalam cerpen Max, BAK, dan potongan cerita Ia Menangis (IM) serta Hidup Terasa Panjang (HTP). Dalam Max, posisi perempuan/wanita berada pada identitas lebih rendah dibandingkan laki-laki. Cerita terkait wanita-wanita dan Martha yang ditinggalkan oleh laki-laki (Max) sebagai suami mereka menandakan pada posisi yang lebih rendah. Perempuan sebagai yang ditinggalkan dan laki-laki sebagai yang meninggalkan. Pada cerpen BAK juga ditemukan perempuan pelacur yang dianggap layak juga untuk ditinggalkan seperti tokoh Ibunya Naro. Ibunya Naro yang bekerja sebagai penari ular juga diketahui berprofesi sebagai pelacur. Akan tetapi, ada satu laki-laki yang berkesan bagi Ibu Naro yang kemudian dijadikan sebagai Ayah Naro. Ayah Naro ini pun ternyata juga pergi meninggalkan Ibu Naro tanpa ada kejelasan apa-apa. Ibu Naro harus bertanggung jawab dalam kehidupan dirinya dan kepada anaknya, Naro.

““"Bapakmu itu bangsat!” Ibunya pernah berkata begitu. Bangsat, pikirnya, apakah bangsat itu? Naro tidak pernah tahu betul apa yang dimaksud ibunya jika sudah bicara dengan mulut berbau minuman, mata setengah tertutup seperti mata ular, susah payah mencoba menghapus make up dalam keadaan teler ketika pulang malam-malam.

“Aku kerja banting tulang dan dia hilang entah ke mana. Dasar bajingan!'”, (Ajidarma, 2005, 124)

Di dalam potongan cerita IM, wanita yang bekerja sebagai pekerja malam didapati oleh tokoh Aku sedang menangis. Tidak ada cerita mengenai mengapa wanita itu menangis. Cerpen ini hanya hendak mencuplikkan bahwa ada peristiwa saat wanita-wanita pekerja malam ini mengalami peristiwa yang tidak menyenangkan, ditinggalkan, dan dicampakkan sendirian, bahwa mereka dapat diperlakukan demikian. Sementara itu, di dalam HTP, wanita yang sudah tua semakin rendah posisi di dalam identitasnya sehingga mereka layak untuk ditinggalkan karena sudah tidak mampu memberi kenikmatan bagi laki-laki kaya. "Katanya ia sudah dua tahun kos di sini. Ia punya dua anak di tempat asalnya. Pernah jadi piaraan orang kaya. Kini tercampak dan makin tua" (Ajidarma, 2005, 36). Dalam potongan cerita yang lain, inklusifitas "wanita malam" adalah menjadi istri "gelap", yaitu menjadi istri simpanan atau istri bukan yang pertama seperti dalam Pertemuan yang Batal.

Sekalipun cerpen yang satu dengan yang lainnya berbeda tokoh dan peristiwa, akan tetapi pasangan oposisi dapat ditemukan baik secara eksplisit maupun implisit. Secara eksplisit, oposisi yang dominan dapat ditemukan pada identitas wanita pelacur dengan identitas lain seperti dokter yang ada dalam potongan cerita Orang-orang Sakit Kelamin (OSK), guru dalam cerpen PM, istri pejabat, perempuan-perempuan lain yang ada di dalam cerpen dan beberapa oposisi identitas pelacur secara implisit seperti penari telanjang/ ular dengan penari seni dan penyanyi bar dengan penyanyi lain atau dapat dioposisikan dengan wanita yang ada di dalam cerpen yang lain.

Dalam potongan cerita OSK, tokoh aku bercerita tentang pengalamannya pada saat mendatangi sebuah praktik dokter karena merasa dirinya sedang sakit. Si Aku mengenal dokter tersebut karena sering dijumpainya datang ke bar tempatnya bekerja. Si Aku merasa heran mengapa seorang dokter dengan profesi yang 
membanggakan malah mau datang ke tempat yang dianggap tokoh aku sebagai tempatnya orang-orang sakit, orang-orang yang tidak tahu melakukan apa, orang-orang yang tidak suka membaca buku, orang-orang berselera rendah, kerjanya cuma mabuk dan memeluki wanitawanita. Orang-orang yang mengunjungi doker itu adalah orang-orang berpenyakit kelamin. Hal ini diketahui oleh si Aku setelah dokter mengatakan pasien bernama Eva (penyanyi bar) berpenyakit kelamin.

Dalam pandangan si Aku, orang-orang yang bekerja di bar dan orang-orang yang datang menempatkan pada posisi yang lebih rendah dibandingkan orang yang berprofesi sebagai dokter. Bekerja menjadi dokter merupakan hal yang terhormat, punya selera yang tinggi. Akan tetapi, si dokter ini justru sering mengunjungi bar dan berpacaran dengan seorang penyanyi bar yang berpenyakit kelamin. Posisi dokter sebagai yang terhormat, profesi yang bermartabat, justru dimasukkan ke dalam posisi orang-orang yang dianggap tidak bermartabat tersebut.

Logika dominan juga terlihat pada posisi hierarkis dalam cerpen PM dan beberapa cerpen lain yang dioposisikan dengan identitas pelacur yang juga terdapat dalam cerpen BAK, Episode, Catatan Sepanjang Malam (CSM) dan seluruh cerita di dalam potongan cerita. Dalam cerpen PM posisi lebih tinggi/bermartabat ini ditunjukkan pada identitas guru dan dalam cerpen Ratih, Dewi, Max, Lonely Lover Symphony (LLS), dan ITR ditunjukkan pada wanita baik sebagai istri pejabat atau yang berprofesi sebagai wanita yang bukan pelacur. Pada cerpen yang dioposisikan wanita bukan sebagai pelacur merupakan cerpen yang bukan secara eksplisit bercerita tentang kehidupan pelacur, melainkan identitas wanita yang ada di dalam cerpen terdapat hubungan hierarki yang beroposisi. Cerpen-cerpen seperti Ratih, Dewi, Max, LLS, dan ITR menggambar sosok wanita yang berstatus sebagai istri seorang pejabat atau istri seorang yang memiliki pekerjaan yang bagus, hal ini direpresentasikan melalui tokoh Ibu Ratih (Ratih), tokoh Dewi (Dewi), Martha (Max), Marga (LLS), dan Ibu (ITR).

Di dalam PM, Ibu Guru Tati menempatkannya pada posisi yang lebih terhormat diban- dingkan Ibunya Sandra yang bekerja sebagai pelacur. Sebagai guru, Ibu Guru Tati memberi pelajaran dan pendidikan kepada murid-murid terutama dalam pelajaran mengarang. Guru yang dipandang mulia, berpendidikan, teladan, santun berbanding terbalik dengan Marti dan Mami yang kasar, pemabuk, liar, pemarah. Akan tetapi, perintah Ibu Guru Tati justru membuat Sandra tidak mampu melakukannya karena judul karangan yang diberikan membuat Sandra membayangkan kenyataan yang tidak menyenangkan dalam hidupnya. Sandra membayangkan bagaimana kehidupannya tinggal bersama ibunya dan Mami dengan latar tempat prostitusi.

Sepanjang waktu pelajaran mengarang, Sandra kesulitan untuk mengarang. Sandra ingin jujur menulis pengalamannya. Sementara itu, Ibu Guru Tati menginginkan anak-anak mengarang dan menganggap anak-anak memiliki pengalaman hidup bahagia yang sama. Hidup sebagai anak pelacur, Sandra tidak memiliki pengalaman yang menyenangkan seperti anak yang memiliki orang tua lengkap lainnya. Sampai di akhir pelajaran, Sandra tetap mengumpulkan kertas tulisannya. Di rumah, Ibu Guru Tati memeriksa tulisan dan menemukan tulisan Sandra hanya dengan sepotong kalimat: "Ibuku seorang pelacur...". Sekalipun Sandra adalah anak pelacur, ia masih dipelihara dan disekolahkan oleh Ibunya. Padahal ibunya Sandra yang secara hierarkis lebih rendah daripada profesi guru sebagai yang kasar, pemabuk, dan sebagainya tetap memberikan kasih sayang kepada Sandra. Cerpen ini dan beberapa cerpen yang lain tetap memperlihatkan bahwa wanita yang berstatus baik sebagai istri pejabat dan profesi lainnya menempatkan mereka pada posisi yang lebih terhormat, santun, dan wibawa dibandingkan pelacur yang kasar, liar, pemarah, pemabuk dan sebagainya. Padahal, tokoh-tokoh wanita tersebut tidak serta merta mengalami kebahagiaan dengan posisinya yang terlihat lebih tinggi, bermartabat, dan berwibawa.

\section{Pelacur sebagai Jejak (Trace)}

Dari hasil metode rekonstruksi teks, ditemukan logika dominan dari penanda yang saling beroposisi hingga membentuk struktur hierarki. Penanda pelacur dengan berbagai identitasnya, 
seperti pemijat, penyanyi bar, penari telanjang, waitress, pekerja malam yang ada di dalam cerpen beroposisi dengan penanda, seperti lakilaki, tamu, bos, dokter, guru, dan istri pejabat. Di dalam oposisinya, penanda pelacur berada pada posisi makna yang direndahkan. Pelacur mendapatkan rantai penanda seperti "hina", "tidak bermartabat", "tidak bermoral", "kasar", "liar", "pemarah", "pemabuk", "layak dibunuh", "penyakitan", "perusak rumah tangga" dan sebagainya. Sementara itu, penanda laki-laki, tamu, bos, dokter, guru, dan istri pejabat dengan rantai penanda "berwibawa", "santun", "terhormat", "bersih" berada pada posisi yang lebih tinggi. Padahal menurut Mulia, T.S.G. dkk, dalam Ensiklopedia Indonesia (dalam Kartono, 2005, 184) dijelaskan bahwa pelacuran itu bisa dilakukan baik oleh kaum wanita maupun pria. Akan tetapi, di dalam cerpen, struktur hierarki laki-laki lebih istimewa dibandingkan perempuan. Perempuanlah yang ditempatkan dalam posisi hierarki yang rendah seperti Eva (penyanyi bar) yang berpenyakit kelamin, Marti dan Mami dalam PM yang dianggap kasar, pemabuk, liar, pemarah, dan beberapa perempuan lainnya yang dianggap sebagai perusak rumah tangga serta layak dibunuh. Sementara itu, laki-laki dan perempuan yang memiliki identitas seperti guru dan istri pejabat tidak mendapatkan penanda-penanda buruk meskipun memiliki andil di dalam peristiwa dalam cerpen.

Terbentuknya struktur hierarki tersebut tidak lepas dari penanda sebelumnya. Di dalam definisinya, pelacur memiliki makna tunggal (sebagai yang buruk). Pelacur di dalam KBBI daring (Badan Pengembangan dan Pembinaan Bahasa, 2016) berarti perempuan yang melacur, wanita tunasusila, dan sundal. Pelacur berasal dari kata "lacur" yang berarti malang, celaka, sial, dan buruk laku. Berbagai penanda konotatif lainnya juga mengikuti dari kata tersebut, utamanya bagi orang yang melakukannya. Menurut masyarakat luas, pelacuran dipandang rendah dari sudut moral dan akhlak, dosa menurut agama, tercela dan tidak pantas menurut penilaian budaya masyarakat di Indonesia (Burlian, 2016, 203). Derrida tidak sepakat dengan makna yang tunggal (logos). Bagi Derrida rantai penandaan tidak pernah berakhir. Selalu saja muncul potensi-potensi makna lain yang tersembunyi. Dengan kata lain, setiap penanda selalu ada trace (pemaknaan sebelumnya).

Mulai dari definisi, kategori patologi, hingga nilai di dalam masyarakat maupun agama meletakkan makna pelacur sebagai identitas yang hina dan rendah. Di dalam konsep oposisi biner, suatu penanda niscaya memiliki penanda lain sebagai oposisinya. Jika ada identitas yang dilabelkan hina dan rendah, selalu ada yang dilabelkan mulia dan tinggi/terhormat. Oleh karena itu, modus terbentuknya struktur hierarki tidak dapat dilepaskan dari konsep oposisi biner di dalam penanda sebagai permainan bahasa.

Di dalam ANM, makna pelacur dalam perspektif dekonstruksi tidak berhenti pada pemaknaan secara definisi, kategori patologi, nilai, moral, akhlak di dalam masyarakat. Pelacur dan berbagai penanda oposisinya memiliki jejak makna lain yang dapat dijadikan pemaknaan yang baru. Laki-laki yang berprofesi sebagai dokter di dalam potongan cerita OSK juga memiliki penyakit kelamin, laki-laki sebagai suami di dalam BAK juga dianggap sebagai bajingan, istri pejabat di dalam Ratih dan guru di dalam PM adalah seorang yang tidak jujur, istri pejabat yang ada dalam potongan cerita Pembunuhan adalah perempuan pembunuh.

Hal ini menandakan bahwa pemaknaan yang tunggal pada pelacur sebagai struktur hierarki yang rendah dan hina akan selalu problematis. Selalu ada potensi jejak lain yang pada akhirnya membalikkan posisi struktur hierarki tersebut. Pelacur berada pada jejak penanda yang lebih tinggi dari pada penanda oposisinya. Nilai, moral, akhlak yang ada pada masyarakat dapat saja menjadi penanda bagi pelacur, seperti orang yang bertanggung jawab, jujur, penolong (heroic), dan sebagainya.

\section{Invensi Makna Pelacur}

Derrida $(1992,312)$ mengungkapkan bahwa " $A n$ invention always presupposes some illegality, the breaking of an implisif contract; it insert a disorder into the peaceful ordering of things, it disregards the proprieties" (suatu invensi selalu mengandaikan semacam ilegalitas, pelanggaran suatu kontrak implisit; invensi memasukkan suatu 
ketidakteraturan ke dalam tatanan harmoni berbagai hal, invensi mengabaikan hal umum yang dianggap benar). Lebih lanjut Derrida $(1992,312)$ mengatakan "There is no natural invention-and yet invention also presupposes originality, a relation to origins, generation, procreation, genealogy, that is to say, a set of values often associated with genius or geneality, thus with naturality."

Dalam kumpulan cerpen ANM ini, posisi wanita/perempuan yang ditempatkan pada hierarki yang rendah justru berada pada sebaliknya. Profesi-profesi sebagai massage-girl, waitress, penyanyi bar, penari telanjang berada pada posisi yang membahagiakan para tamu yang justru tidak menemukan kebahagiaannya di tempat lain. Wanita-wanita ini menjadi tempat atau ruang bagi tersalurkannya segala emosi yang didapat baik dari pekerjaan atau masalah rumah tangga. Profesi sebagai dokter pun tidak mampu mendapatkan kebahagiaan diri sehingga ia harus mencarinya ke bar, ke seorang wanita malam.

"Apakah dokter ini tidak punya pilihan lain? Aneh kalau ia belum beristri. Wajahnya tampan, bersih, dan mengesankan. Mungkin ia hanya mencari kepuasan pada diri Eva. Wanita itu dalam Apocalypse memang terkenal luwes. Bersedia memberi pelayanan macam apapun." (Ajidarma, 2005, 44)

Laki-laki yang mencari kepuasan dari wanita lain (pelacur) justru tidak menemukan kepuasan terhadap pasangan legalnya (istri). Pengetahuan mereka terhadap berbagai pelayanan yang memuaskan justru menjadikan para pelacur lebih berpengetahuan (tentang seks) dari pada istri pejabat dalam ITR atau istri dari suami yang meninggalkan atau mencari kepuasan di luar seperti dalam Ratih, Dewi, dan Max. Mereka (pelacur) justru menjadi penyelamat bagi laki-laki yang stress akibat tuntutan identitas pekerjaan atau penanda-penanda lainnya, seperti menjadi suami yang bertanggung jawab dan tokoh publik. Pihak laki-laki pulalah yang justru menjadi "perusak rumah tangga" karena mereka sendiri yang datang ke tempat pelacur bekerja. Pelacur dalam hal ini hanya mengharapkan imbalan dari jasa pelayanan yang diberikannya. Akan tetapi, pihak laki-laki yang menentukan pilihannya sendiri untuk membentuk rumah tangga yang harmonis. Rumah tangga wanita yang menembak pelacur itu semakin rusak karena telah melakukan pembunuhan (dalam potongan Pembunuhan). Perempuan pembunuh itu akan ditangkap dan anak-anak mereka bisa terlantar. Dalam hal ini, pelacurlah yang justru menjadi korban.

Dalam cerpen ITR, ketidakharmonisan keluarga itu disebabkan oleh sang bapak yang sebagai seorang pejabat, publik figur melakukan aib bagi keluarga. Aib ini tidak boleh diketahui oleh anakanak mereka. Istri yang kecewa pada akhirnya juga pergi bersama laki-laki lain meninggalkan keluarga. Anak dalam cerpen itu bisa saja bukan sebagai anak kandung dari ibu tersebut, melainkan hasil dari perselingkuhan si bapak. Hal ini menandakan bahwa persoalan perusak rumah tangga bukan disebabkan oleh pelacur melainkan oleh laki-laki/suami. Perempuan sebagai istri yang memiliki hierarki menempatkan pada posisi yang terhormat justru tidak menemukan kehormatannya. Tokoh Dewi dalam Dewi tidak menemukan kebahagiaannya bersama suami sekalipun ia hidup dalam kebercukupan. Hal yang juga serupa terungkap dalam cerpen Max dan LLS.

Dalam cerpen PM, pelacur menemukan makna yang lain dalam oposisinya terhadap profesi yang dianggap terhormat, mulia, dan panutan, yaitu guru. Pelacur yang dikonotasikan sebagai yang pemarah dan pemabuk justru tidak lagi stabil sebagai pemaknaan sebelumnya. Ada invensi makna pelacur yang terdapat pada tokoh Marti dan Mami. Dalam cerpen PM, Sandra yang merupakan siswa SD diminta untuk mengarang oleh Ibu Guru Tati pada saat jam pelajaran bahasa Indonesia. Guru yang seharusnya menjadi panutan atau teladan malah dibenci oleh Sandra karena memintanya untuk mengarang topik yang tidak pernah dialaminya. Dua topik yang diberikan tidak mampu dilakukan Sandra, sedangkan topik Ibu, Sandra tidak mampu untuk menceritakan tentang hal-hal yang dialami oleh anak pada umumnya. Meskipun tulisan Sandra hanya sepotong kalimat yang menyatakan ibunya seorang pelacur, hal ini menandakan bahwa ia merupakan anak yang jujur, tidak mau menutupi pekerjaan ibunya yang dicap buruk. Dari mana nilai kejujuran ini ia peroleh? Apakah dari Ibu Guru Tati yang justru memintanya untuk mengarang? Nilai 
kejujuran Sandra diterima dari Ibunya atau Mami yang menjaganya. Marti secara tidak langsung mengajarkan kejujuran kepada anaknya bahwa jangan seperti dirinya yang menjadi pelacur.

"Berjanjilah pada Mama, kamu akan jadi wanita baik-baik, Sandra."

"Seperti Mama?"

"Bukan, bukan seperti Mama. Jangan seperti Mama." (Ajidarma, 2005, 77)

Hal ini menandakan bahwa Marti yang pelacur adalah seorang yang jujur. Berbeda dari tokoh Ibu yang ada dalam cerpen Ratih. Tokoh Ibu justru seolah percaya akan cerita Ratih yang melihat ada mayat di sungai, padahal Ibu Ratih tersebut tidak percaya dan menganggap Ratih berkhayal. Tokoh Ibu Ratih justru tidak jujur kepada anaknya. Hal yang tentu bertolak belakang dari Marti. Hal ini juga sama seperti tokoh Ibu dalam ITDR yang tidak mau jujur terkait aib keluarga kepada anaknya. Selain itu, Sandra yang tinggal bersama ibunya dan ia disekolahkan oleh Ibunya menandakan bahwa sang ibu bertanggung jawab terhadap anaknya. Sejak muncul dalam kandungan dan memeliharanya hingga besar merupakan komitmen bagi si Ibu. Sikap tanggung jawab ini juga diperlihatkan oleh Mami yang menjaga Sandra pada saat ibunya pergi ke luar kota.

\section{"Anak kecil kok dibawa ke sini, sih?” \\ "Ini titipan si Marti. Aku tidak mungkin mening- galkannya sendirian di rumah. Diperkosa orang malah repot nanti." (Ajidarma, 2005, 76)}

Dalam hal ini, pelacur menemukan maknanya sebagai orang yang bertanggung jawab. Berbeda dari laki-laki yang diceritakan pada beberapa potongan cerita dan di dalam cerpen ITR, Max, dan BAK yang menggambarkan orang yang tidak bertanggung jawab. Ibu dalam ITR malah meninggalkan anak-anaknya, Max malah meninggalkan istri-istrinya, dan Bapak dalam BAK meninggalkan ibunya dan anaknya, Naro. Tidak bertanggung jawab terhadap keluarganya menandakan bahwa tokoh-tokoh yang dianggap lebih tinggi posisinya malah menjadi orang yang tidak memiliki kasih sayang kepada keluarga. Berbeda dari apa yang diperlihatkan Marti dengan menyayangi Sandra yang mengajaknya jalan-jalan dan membelikannya es krim.
Struktur hierarki yang menempatkan pelacur pada posisi yang terendah, hina, dan sebagainya justru menemukan invensi makna yang baru di dalam kumpulan cerpen ANM ini. Statusnya sebagai pekerja malam tidak serta merta membuat pelacur ini lebih rendah derajatnya dari para pekerja pagi atau siang. Mereka juga sama, bekerja sebagai pemberi jasa dan menerima upah. Sebagai perempuan, mereka tidak lebih hina dari pada laki-laki karena mereka justru yang menjadi korban atas rusaknya rumah tangga sebuah keluarga. Oleh karena itu, mereka juga tidak layak untuk diperlakukan semena-mena, bahkan dibunuh. Menjadi dokter, guru, dan identitas lain tidak menjadikan posisi ini lebih tinggi dari pelacur. Makna pelacur bukan lagi perusak rumah tangga, melainkan dapat menjadi pahlawan atau penolong bagi mereka yang mengalami depresi dalam pekerjaan atau rumah tangga. Menjadi pahlawan, pelacur menemukan maknanya yang baru pada diri Marti yaitu menjadi pahlawan/ penolong bagi anaknya Sandra. Tambahan pula, Marti adalah sosok yang bertanggung jawab terhadap keluarganya. Invensi makna baru pelacur ini menandakan bahwa ada yang inkonsisten dan kontradiktif di dalam teks. Teks yang menempatkan pelacur sebagai yang buruk telah digagalkan sendiri di dalam cerpen. Makna pelacur tidak lagi secara tunggal dicap buruk, tetapi juga memiliki makna kebaikan.

\section{PENUTUP}

Berdasarkan pembahasan di atas, dapat disimpulkan bahwa pengklasifikasian melalui oposisi biner menjadi cara melihat sudut pandang masyarakat terkait dengan makna pelacur dan menemukan cara pandang baru. Oposisi biner pelacur ini diklasifikasikan secara eksplisit dan implisit antara satu cerpen dengan cerpen yang lainnya. Klasifikasi oposisi biner pelacur yang ada di dalam kumpulan cerpen ANM ini adalah wanita dengan laki-laki, sebagai pekerja malam dengan pekerja pagi/siang, boleh dibunuh dengan pembunuh, perusak rumah tangga dengan pembentuk rumah tangga harmonis, pelacur dengan dokter, pelacur dengan guru, dan pelacur dengan istri pejabat. 
Setelah menemukan berbagai oposisi biner di dalam cerpen, hasil dari rekonstruksi menemukan bahwa adanya struktur teks dengan logika dominan yang terdapat dalam teks menjadikan atau menempatkan pelacur (sebagai perempuan dan bekerja di malam hari) pada posisi yang rendah, hina, tidak bermartabat, yaitu sebagai perempuan perusak rumah tangga, sebagai orang yang berhak ditinggalkan, sebagai orang yang layak dibunuh, dan dengan karakternya yang buruk (pemabuk, pemarah, dan perokok). Sementara itu, orang-orang seperti laki-laki, pekerja di pagi/siang hari, sebagai dokter, istri pejabat, dan guru menempatkan mereka pada posisi yang lebih tinggi, bermartabat, terhormat, pahlawan, dan sebagainya.

Hasil pembacaan dekonstruksi adalah invensi. Invensi ini ditemukan setelah terjadi kontaminasi antara penanda pelacur dengan penanda lain seperti laki-laki, dokter, istri pejabat, guru, dan orang-orang yang bukan bekerja pada malam hari yang membentuk hierarki. Pembacaan rekonstruksi menemukan bahwa hierarki penanda tersebut tidak dapat dipertahankan karena adanya logika dominan yang menemukan bahwa makna pelacur tidak lagi berada pada posisi yang rendah. Makna pelacur dalam kumpulan cerpen ANM ini menemukan makna baru bahwa pelacur atau mereka yang hidup dalam dunia malam tidak menjadikan mereka lebih rendah dari mereka yang bekerja di pagi atau siang hari. Mereka justru memberi jasa pelayanan yang tidak didapat dari kehidupan selain malam. Pelacur juga bukan satu-satunya dianggap sebagai perusak rumah tangga keluarga, melainkan pihak laki-laki (suami) yang menjadi penentu kondisi rumah tangga mereka. Justru, pelacurlah yang menjadi korban dari rusaknya rumah tangga. Dalam hal ini, pelacur malah memiliki pengetahuan akan seks dibandingkan istri atau perempuan yang ditinggalkan oleh suaminya. Pelacur justru menjadi sosok penolong dan pahlawan bagi orang lain dan mereka bertanggung jawab terhadap orang lain. Mereka juga adalah orang-orang jujur dengan mengakui apa adanya kondisi mereka. Inilah logika baru (invensi) makna pelacur yang tidak dapat dikembalikan pada hierarkis sebelumnya.

\section{REFERENSI}

Ajidarma, S G. (2005). Atas nama malam. Jakarta: Gramedia Pustaka Utama.

Al-Fayyadl, M. (2011). Derrida. Yogyakarta: LkiS Pelangi Aksara Yogyakarta.

Badan Pengembangan dan Pembinaan Bahasa. (2016). Pelacur. Dalam Kamus besar bahasa Indonesia (KBBI) daring. Diakses dari https://kbbi. kemdikbud.go.id/entri/pelacur, pada13 Oktober 2020.

Barry, P. (2010). Pengantar komprehensif teori sastra dan budaya: Beginning theory. Yogyakarta: Jalasutra.

Bradley, A. (2008). Derrida's of grammatology: An Edinburgh philosophical guide. Edinburgh: Ediburgh University Press.

Burlian, P. (2016). Patologi Sosial. Jakarta: PT Bumi Aksara. Retrieved from http://eprints.radenfatah.ac.id/4126/1/17. BUKU PATOLOGI SOSIAL.pdf

Caputo, J. D. (1986). Radical Hermeneutics. Philosophy Today. https://doi.org/10.5840/ philtoday 198630416

Culler, J. (2001). The Persuit of Signs. New York: Routledge.

Dahlan, M. M. (2005). Tuhan Izinkan Aku jadi Pelacur. Yogyakarta: Scripta Manent.

Derrida, J. (1976). Of grammatology (C. Gayatri, trans.). Spivak. Baltimore: The John Hopkins University Press.

Derrida, J. (1992). Pysche: Invention of the other. Dalam D. Atridge (Ed.), Jacques Derrida: Acts of literature. New York. Routledge.

Derrida, J. (1998) Positions, (A. Bass, trans.). Chicago: The University of Chicago Press.

Faruk. (2012). Metode penelitian sastra: Sebuah penjelajahan awal. Yogyakarta: Pustaka Pelajar.

Imron, A. (2015). Dekonstruksi kultural terhadap feminisme dan dekonstruksi feminis terhadap kultur dalam cerpen Malam Pertama Seorang Pendeta. Transformatika: Jurnal Bahasa, Sastra, dan Pengajaranya, 11(2), 71-79. https:// jurnal.untidar.ac.id/index.php/transformatika/ article/view/214/166.

Kartono, K. (2005). Patologi sosial. Jakarta: Raja Grafindo Persada.

Kiki, A. (2015). Konflik Batin Tokoh Utama dalam Kumpulan Cerpen Atas Nama Malam Karya Seno Gumira Ajidarma. Skripsi S1. STKIP PGRI Sumbar. 
Mustika, (2014). Eksistensi Pelacur dalam Novel Tuhan, Izinkan Aku Menjadi Pelacur. Tesis S2. UGM.

Norris, Christopher. (2006). Membongkar Teori Dekonstruksi Jacques Derrida. Yogyakarta: Ar-Ruzz Media.

Pratiwi, L. (2014) Dekonstruksi Pelacur dalam Novel Chrysan Karya Hapie joseph Aloysia. Tesis S2. UGM.

Rahardi, F. (1983). Soempah wts: kumpulan sajak. Jakarta: Puisi Indonesia.

Rendra, W. S. (2013). Blues untuk Bonnie. Cirebon: Pustaka Jaya.

Tohari, A. (2011). Ronggeng Dukuh Paruk. Jakarta : PT Gramedia Pustaka Utama.
Ungkang, M. (2013). Dekonstruksi Jaques Derrida sebagai Strategi Pembacaan Teks Sastra. Jurnal Pendidikan Humaniora. https://doi. org/10.17977/JPH.V1I1.3919

Worcester, A. (2002). Pelacuran dalam Konteks Budaya. Malang. Retrieved from https://www. acicis.edu.au/wp-content/uploads/2015/03/ WORCESTER-Adelaide.pdf

Sarup, M. (2003). Post-Strukturalisme and postmodernisme: Sebuah pengantar kritis. Yogyakarta: Jendela.

Situmeang, M. K. (2016). Dekonstruksi makna memakai "Boh Gaca" (Memakai Inai) pada Masyarakat Aceh dalam kajian Jaques Derrida. Jurnal Sosiologi USK, 10 (2), 140-141. 